\title{
Christian Soldiers: The Meaning of Revivalism in the Confederate Army
}

\section{Citation}

Faust, Drew G. 1987. Christian soldiers: The meaning of revivalism in the Confederate army. The Journal of Southern History 53(1): 63-90.

\section{Published Version}

http://dx.doi.org/10.2307/2208627

\section{Permanent link}

http://nrs.harvard.edu/urn-3:HUL.InstRepos:2634138

\section{Terms of Use}

This article was downloaded from Harvard University's DASH repository, and is made available under the terms and conditions applicable to Other Posted Material, as set forth at http:// nrs.harvard.edu/urn-3:HUL.InstRepos:dash.current.terms-of-use\#LAA

\section{Share Your Story}

The Harvard community has made this article openly available.

Please share how this access benefits you. Submit a story.

Accessibility 


\title{
Christian Soldiers: The Meaning of Revivalism in the Confederate Army
}

\author{
By Drew Gilpin Faust
}

F ROM THE FALL OF I 862 UNTIL THE LAST DAYS OF THE CIVIL WAR,
religious revivalism swept through Confederate forces with an inten-
sity that led one southerner to declare the armies had been "nearly
converted into churches." ${ }^{\text {A }}$ remarkable phenomenon in the eyes of
contemporary observers, these mass conversions have been largely
ignored by modern scholars. ${ }^{2}$ The attention recent historians have
devoted to other manifestations of nineteenth-century Evangelical-
ism makes this neglect of Civil War religion seem all the more curi-

1 "Rev. A. E. Dickinson's Annual Report to the General Association of Va.," Confederate Baptist, June 24, 1863. I would like to thank the Stanford Humanities Center, the several audiences who made helpful comments on preliminary versions of this paper, and especially Lizabeth Cohen, Steven Hahn, Randall Miller, Reid Mitchell, Charles Rosenberg, and Morton Sosna for their suggestions and criticism.

${ }^{2}$ For example, James M. McPherson's excellent recent overview of the war does not mention the revivals. See Ordeal by Fire: The Civil War and Reconstruction (New York, 1982). The best discussion of the revivals is still Bell Irvin Wiley, "Consolations of the Spirit," Chap. 10 in The Life of Johnny Reb: The Common Soldier of the Confederacy (1943; rpt. ed., Baton Rouge, 1978), but in my view Wiley underestimates their significance. See also Gorrell Clinton Prim, Jr., "Born Again in the Trenches: Revivalism in the Confederate Army" (unpublished Ph.D. dissertation, Florida State University, 1982), for a recent but largely unanalytical account. Equally unanalytical are G. Clinton Prim, Jr., "Revivals in the Armies of Mississippi During the Civil War,” Journal of Mississippi History, XLIV (August 1982), 227-34; Herman Norton, "Revivalism in the Confederate Armies," Civil War History, VI (December 1960), 410-24; John Shepard, Jr., "Religion in the Army of Northern Virginia," North Carolina Historical Review, XXV (July 1948), 341-76; Sidney J. Romero, Religion in the Rebel Ranks (Lanham, Md., New York, and London, 1983); and Benjamin Rice Lacy, Jr., Revivals in the Midst of the Years (Richmond, 1943). Two accounts published shortly after the war by participants are useful. See J. Wm. Jones, Christ in the Camp: or Religion in Lee's Army (Richmond, 1887); and William W. Bennett, A Narrative of the Great Revival in the Southern Armies . . . (Philadelphia, 1877). A work that appeared after the completion of this essay deals in some detail with the role of religion during the war, although it does not devote particular attention to its significance in the Confederate army. See Richard E. Beringer, Herman Hattaway, Archer Jones, and William N. Still, Jr., Why the South Lost the Civil War (Athens, Ga., and London, 1986). For my reservations about their viewpoint see Drew Gilpin Faust, "Reassessing the Lost Cause of the South," Books/Leisure, Philadelphia Inquirer, June 29, 1986, pp. 1, 8-9.

Ms. Faust is a professor of American Civilization at the University of Pennsylvania.

The Journal of Southern History

Vol. LIII, No. 1, February 1987 
ous, for scholarly findings about the relationship between revivalism and the processes of social and cultural transformation suggest that an exploration of army Evangelicalism should yield important insights into the meaning of the South's experience in an era of profound dislocation and change. ${ }^{3}$

The centrality of religion within antebellum southern culture gave sacred language and perception a prominent place in the region's response to war. The South had not only embraced evangelical Protestantism with a uniformity and enthusiasm unmatched in the rest of the nation but had also used religion as a crucial weapon in the sectional propaganda battle. Defining itself as more godly than the North, the South turned to the Scriptures to justify its peculiar institution and its social order more generally. With its declaration of nationhood and the subsequent outbreak of war, the Confederacy identified its independence and success as God's will. Their cause, southerners insisted until the very last days of the conflict, was God's cause; the South's war of defense against invasion was unquestionably a just war.

The prominence of such sentiments in public discourse-in the Confederate Constitution itself, in Jefferson Davis's proclamations of fast days, in generals' announcements of military victory, not to mention in church sermons and denominational publications established religion as the fundamental idiom of national and personal identity; southerners' responses to the unanticipated horrors of the first modern, total war were almost necessarily articulated within a religious framework and in religious language. But if religion was central to the Confederacy as a whole, it was perhaps of greatest importance to the common southern soldier, whose life was most dramatically altered - if not actually ended - by war's demands. The widespread army revivals directly reflected the stresses of the soldier's life and death situation: the strains of life in the ranks of a mass army; the pressures of daily confrontation with death - and with a rate of mortality unmatched in any American war before or since. ${ }^{4}$

\footnotetext{
${ }^{3}$ For a useful overview of this literature see Leonard I. Sweet, "The Evangelical Tradition in America," in Leonard I. Sweet, ed., The Evangelical Tradition in America (Macon, Ga., 1984), 1-86.

${ }^{4}$ See Donald G. Mathews, Religion in the Old South (Chicago and London, 1977); Samuel S. Hill, Jr., The South and the North in American Religion (Athens, Ga., 1980); John B. Boles, The Great Revival, 1787-1805: The Origins of the Southern Evangelical Mind (Lexington, Ky., 1972); Anne C. Loveland, Southern Evangelicals and the Social Order, 18001860 (Baton Rouge, 1980); Dickson D. Bruce, Jr., And They All Sang Hallelujah: Plain-Folk Camp-Meeting Religion, 1800-1845 (Knoxville, 1974); Drew Gilpin Faust, ed., The Ideology of Slavery: Proslavery Thought in the Antebellum South, 1830-1860 (Baton Rouge and London, 1981); James W. Silver, Confederate Morale and Church Propaganda (Tuscaloosa, Ala., 1957); and William A. Clebsch, "Christian Interpretations of the Civil War," Church History, XXX (June 1961), 212-22. On the Civil War as total war see T. Harry Williams, The
} 
Although the southern religious press reported scattered conversions of soldiers from the time fighting broke out, Confederates did not begin to identify what one Evangelical called a "genuine and mighty work of grace" until the fall of $1862 .{ }^{5}$ At first confined to the Army of Northern Virginia, and always strongest there, significant religious awakenings spread to the Army of Tennessee and to the Trans-Mississippi forces in 1863 and $1864 .{ }^{6}$ One observer later calculated that as many as 150,000 soldiers were "born again" during the war, but even if far fewer actually converted, thousands more participated in the revival without themselves undergoing the dramatic personal experience of grace. ${ }^{7}$

For large numbers of men the struggle against the Yankees on the field had its parallel in the battle against Satan in the camp. Soldiers' diaries and letters make clear how widely the phenomenon extended. As one participant expressed it, "We sometimes feel more as if we were in a camp-meeting than in the army expecting to meet an enemy'." A less sympathetic observer found he could not even write a peaceful letter to his wife. "It seems to me that whereever [sic] I go I can never get rid of the 'P-salm-'singers - they are in full blast with a Prayer meeting a few rods off . . . " To many of those neither directly involved nor firmly opposed, the pattern of Evangelicalism and conversion became simply a part of army routine. One captain wrote indifferently yet revealingly in his diary in mid-1863, "Today is Sunday. Nothing unusual. . . . -preaching in the afternoon and evening. Many joined the church." ${ }^{8}$

History of American Wars From 1745-1918 (New York, 1981); Russell F. Weigley, The American Way of War: A History of United States Military Strategy and Policy (New York, 1973); and Jay Luvaas, The Military Legacy of the Civil War: The European Inheritance (Chicago, 1959). On Evangelicalism as a vehicle of national organization and integration see Donald G. Mathews, "The Second Great Awakening as an Organizing Process, 1780-1830: An Hypothesis," American Quarterly, XXI (Spring 1969), 23-43.

${ }^{5}$ Jones, Christ in the Camp, 336 (quotation). For examples of early reports of conversions see Religious Herald, August 29, 1861, September 12, 1861, October 17, 1861, April 17, 1862, June 5, 1862, August 21, 1862.

${ }^{6}$ See Jones, Christ in the Camp, Appendix II, 535-624; Lacy, Revivals in the Midst of the Years, 119; James Cooper Nisbet, Four Years on the Firing Line, ed. by Bell Irvin Wiley (1914; rpt. ed., Jackson, Tenn., 1963), 175; "Great Trans-Mississippi Revival," Southern Christian Advocate, August 25, 1864; and Confederate Baptist, June 1, 1864.

7 Jones, Christ in the Camp, 390. For an assessment of different estimates of numbers of converts see Herman Norton, Rebel Religion: The Story of Confederate Chaplains (St. Louis, 1961), 64 .

${ }^{8}$ Jones, Christ in the Camp, 33-34 (first quotation); John Kent Folmar, ed., From That Terrible Field: Civil War Letters of James M. Williams, Twenty-first Alabama Infantry Volunteers (University, Ala., 1981), 13 (second quotation); Anne King Gregorie, ed., "Diary of Captain Joseph Julius Westcoat, 1863-1865," South Carolina Historical Magazine, LIX (January 1958), 13 (third quotation). See also J. Charles Mundy to Beverly Preston Morriss, September 28, 1863, Beverly Preston Morriss Papers (William R. Perkins Library, Duke University, Durham, N. C.; repository hereinafter cited as Duke); and George W. Cherry to Dear Sister, October 7, 1863, Lunceford R. Cherry Papers (Duke). 
When the timing of battle permitted, chaplains and lay preachers organized a prodigious schedule of services - sometimes as many as five or six meetings a day. During a six-week lull in the fighting in Virginia during the summer of $1864-$ a time when the military situation made invocation of divine help particularly appropriate-one brigade chaplain scheduled daily prayers at sunrise, an "inquiry meeting" each morning at eight, preaching at eleven, prayers for the success of the Confederate cause at four, and preaching again at night. ${ }^{9}$

Brigades in which the revival spirit was vigorous often constructed chapels, especially in winter quarters when the men were likely to spend several months in one place. In January 1865 , for example, a Virginian reported that his brigade had erected churches every six to eight hundred yards along the lines. In summer soldiers built outdoor chapels in the woods. Split logs served as benches; a wooden platform became the altar; iron-mesh baskets held firewood to illuminate the gatherings. Even places for two thousand worshippers were often not sufficient. "The interest manifested," one soldier reported, "was so great that the seats were taken in the afternoon by such men as were not on duty. When night relieved from duty those who had been drilling, the men stood up in immense numbers around those who were seated." When observances were held indoors, the smaller number of places made competition even more intense. "Men may sometimes be seen an hour before services running to the house, in order that they may procure seats. They come from regiments two miles off." Men of the Army of Northern Virginia packed one brigade chapel like "herrings in a barrel." 10

The revival spawned as well a major Confederate publishing endeavor. In spite of paper and labor shortages, nearly two hundred million pages of tracts were distributed to soldiers during the war. Several denominations also published religious newspapers for the troops, and the Confederate Bible Society, founded in 1862, hoped to supply every soldier with his own New Testament. When revivalists were unavailable, tracts served as substitutes. "These little preachers," as the Confederate Baptist called them, could be read

\footnotetext{
9 Jones, Christ in the Camp, 504. See also the preaching schedule of John DeWitt McCollough, March through May, 1862, Journal, John DeWitt McCollough Papers (South Caroliniana Library, University of South Carolina, Columbia).

${ }^{10}$ Christian Observer, January 26, 1865; John H. Worsham, One of Jackson's Foot Cavalry. . . . , ed. by James I. Robertson, Jr. (1912; rpt. ed., Jackson, Tenn., 1964), 113-14 (first quotation); Religious Herald, February 11, 1864 (second quotation), October 10, 1861; R. S. Webb to his mother, April 16, 1864, Webb Family Papers (Southern Historical Collection, University of North Carolina, Chapel Hill; repository hereinafter cited as SHC); Central Presbyterian, April 2, 1863 (third quotation). See also Samuel P. Lockhart to Ellen Lockhart, March 14, 1864, Hugh Conway Browning Papers (Duke).
} 
over and over-in the tent, on a march, or even in the heat of battleand were often cited as themselves responsible for conversions. The popularity of tracts and papers grew throughout the war, and Stonewall Jackson was reputed to keep a supply on hand to use as rewards for his men. One Baptist missionary thought that much of the appetite for the publications arose because "the soldiers here are starving for reading matter. They will read anything." But even if their appeal originated in the monotony of camp life, the tracts achieved remarkable effectiveness as an "instrument" in saving souls. Together with the exhortations of missionaries and chaplains, religious publications kept the army's revivalist fervor at a remarkably high pitch."

Curiously, the evangelical fervor of the Confederate troops was not paralleled by enthusiasm at home, and, as self-righteous southerners loved to charge, "nothing like this occurred in the Yankee army." 12 Despite the widespread perception of the conflict as a holy war, southern civilians, even church members, were not experiencing God's grace in substantial numbers. The coldness of established congregations throughout the war years troubled southern clergy, who attributed their failures to the preoccupation of their flocks with the secular realities of politics and economic survival. But surely the Confederacy's soldier-converts were even more concerned with the actualities of war. For them, perhaps, the ever-present threat of death gave battle a transcendent, rather than primarily worldly, significance, or possibly the enthusiasm within the army reflected Evangelicals' concerted efforts with the troops.

The comparison with soldiers' experiences in the northern army is more problematic, for revivals did occur with some frequency among Yankee troops. Most nineteenth-century observers, as well as twentieth-century scholars, have remarked, however, upon significant differences in the scale and in the intensity of army religion North and South. Abraham Lincoln himself worried that "rebel soldiers are praying with a great deal more earnestness . . . than our own troops . . . ." A number of explanations for this contrast seem

11 Confederate Baptist, May 16, 1863 (first quotation); Religious Herald, May 8, 1862, October 10, 1861 (second quotation); James W. Silver, ed., A Life for the Confederacy, as Recorded in the Pocket Diaries of Pvt. Robert A. Moore . . . (Jackson, Tenn., 1959), 95. On tracts see Romero, Religion in the Rebel Ranks, 163; Silver, Confederate Morale and Church Propaganda; and Wiley, The Life of Johnny Reb, 177. Much of the research for this paper was made possible by the availability on microfilm of almost all surviving Confederate tracts and sermons as well as most other extant printed Confederate material. See Confederate Imprints (New Haven, 1974).

12 Religious Herald, April 8, 1864 (quotation). On the lack of religious fervor on the home front see "Revivals at Home," Southern Christian Advocate, September 8, 1864; Biblical Recorder, June 17, 1863; Army and Navy Messenger, March 1, 1864; William Flinn to William Letcher Mitchell, April 24, 1863, William Letcher Mitchell Papers (SHC). 
plausible. The greater homogeneity of religious outlook within the overwhelmingly evangelical and Protestant southern army was certainly significant. The more profound stresses on southern soldiers, who because of shortages of manpower and materiel served for longer periods of time, with fewer furloughs, and with greater physical deprivation, undoubtedly played a role as well, for it was as the war increased in duration and intensity that revivalism began to spread. ${ }^{13}$

Men donning the Confederate uniform did not at first demonstrate unusual piety. At the outset the devoted found themselves very much on the defensive, for religious leaders felt obliged to combat a widespread view that godliness would undermine military effectiveness. There "is nothing in the demands of a just and defensive warfare at variance with the spirit and duties of Christianity," an oft-reprinted tract urged. "Piety will not make you effeminate or cowardly." Godly southerners at first feared that the influences might work in just the opposite direction: that battle would prove an impediment to piety. "War is the hotbed of iniquity of every kind," wrote the Reverend Charles Colcock Jones. The army had in all ages been "the greatest school of vice." History showed that men removed from the restraining, "softening" moral influences of womanhood and hearth easily succumbed to the temptations of camp life. One tract drawing soldiers' attention to the grave yawning open before them pointedly summarized the dilemma. "Men, by associating in large masses, as in camps and cities, improve their talents, but impair their virtues." The South, happily free of significant urban centers, must not now abandon her comforting moral advantage. ${ }^{14}$

The initial experience of camp life seemed to bear out these dire expectations. "I think the majority of the men of our Regt. are becoming very wild $\&$ contracting many bad habits," a private wrote home from Virginia in November 1861. The Sabbath brought "no preaching, no service" to counteract Satan's growing influence. "The religious destitution of the Army," a soldier confided to his diary, "is

\footnotetext{
${ }^{13}$ John G. Nicolay and John Hay, eds., Complete Works of Abraham Lincoln (12 vols.; New York, 1905), VIII, 29-30 (quotation). On comparison with religion in the northern armies see Bell Irvin Wiley, The Life of Billy Yank: The Common Soldier of the Union (New York and Indianapolis, 1952); William Warren Sweet, Methodism in American History (New York, Cincinnati, and Chicago, 1933), 287.

${ }_{14}^{14}$ [Mrs. Frances Blake Brockenbrough], A Mother's Parting Words to her Soldier Boy (Petersburg, Va., [186-]), 3 (first quotation), 5 (second quotation). See also Are You a Soldier? (n.p., n.d.), 1; Charles Colcock Jones to Charles Colcock Jones, Jr., March 24, 1862, in Robert Manson Myers, ed., The Children of Pride: A True Story of Georgia and the Civil War (New Haven and London, 1972), 866 (third quotation). See also Drury Lacy, Address Delivered at the General Military Hospital, Wilson, N. C., . . . (Fayetteville, N. C., 1863), 7; Confederate Baptist, July 6, 1864 (fourth quotation), December 17, 1862 (fifth quotation); The Open Sepulchre (Charlotte, N. C., 1864), 2 (sixth quotation).
} 
awful . . . " By far the largest portion of the troops appeared to one tract agent as entirely godless. Of the three hundred men in three companies that he visited in the summer of 1861 , only seven were "professors of religion." The army presented a moral picture that was "dark indeed." 15

The seeming enormity of the problem inspired religious leaders to rise to meet the challenge. The large number of unconverted could certainly be regarded as a "field . . . white unto the harvest." The Baptist Religious Herald was not alone in viewing the evangelization of the army as the obvious " Christian work of the day." Ministers recognized that the very grimness of the situation they confronted contained seeds of hope. The Confederate army was young; its modal age was eighteen, almost the ideal time for conversion, as southern preachers, versed in what one modern scholar has called the "applied science" of revivalism, understood very well. "Scarcely any" the Reverend James McGready noted in a tract entitled An Appeal to the Young, "are ever converted . . . after the age of twenty-five or thirty years at the farthest"; most were converted well before that time. Soldiers also provided a special opportunity for evangelical labors because they were men, those who before the war had proven "most inaccessible to pastoral influence." Now isolated from home and loved ones and confronted by the reality of death, "even the man who always repulsed the approaches of his pastor at home" might "gratefully receive the attentions of the chaplain." Perhaps in war men could be brought to feel the emotionality and vulnerability that in peacetime had been the almost exclusive domain of the other sex. "There is a foolish notion," one tract explicitly stated, "that it is unmanly to manifest any feeling under the pressure of bereavement or mental distress. . . . that it is womanly and childish to weep." The wartime work of the evangelist was to convince the soldier that "this is all a mistake." The availability of a large congregation, already assembled in camp, and the "contagious nature of army habits," for good as well as evil, further encouraged preachers in their task. ${ }^{16}$

${ }^{15}$ Silver, ed., A Life for the Confederacy, 83 (first quotation); William C. Childers, ed., "A Virginian's Dilemma: The Civil War Diary of Isaac Noyes Smith . . . Sept. to Nov., 1861," West Virginia History, XXVII (April 1966), 184 (second quotation), 199 (third quotation); Religious Herald, June 20, 1861; Biblical Recorder, June 19, 1861 (fourth quotation); Jones, Christ in the Camp, 271 (fifth quotation).

${ }^{16}$ Proceedings of the Ninth Biennial Session, of the Southern Baptist Convention . . . Augusta, Ga., 1863 . . . (Macon, Ga., 1863), 54 (first quotation). See also Jones, Christ in the Camp, 555; Religious Herald, May 16, 1861 (second quotation); $\mathrm{Ja}[\mathrm{me}] \mathrm{s}$. McGready, An Appeal to the Young (Raleigh, [186-]), 2 (third quotation); Donald M. Scott, From Office to Profession: The New England Ministry, 1750-1850 (Philadelphia, 1978), 37; T. C. Teasdale, The Season of Divine Mercy (Raleigh, [186-]), 6; Religious Herald, March 14, 1861 (fourth quotation); B. W. McDonnald, Address to Chaplains and Missionaries (Petersburg, Va., 1863) 2 (eighth quotation), 3 (fifth quotation). Almost two out of 
The mobilization of the southern clergy to confront the wartime challenge paralleled the mobilization of Confederate military resources. Identifying both the hazards and the opportunities that war offered the church, ministers worked to devise a strategy for conquering army camps, and, not incidentally, for making religionand its preachers - a central force in the creation of the new nation. With the successes of the church among the troops, a chaplain declared to a gathering of his colleagues, "the foundation for a wide religious power over the country is now lain. . . . We, then, here and now, stand at the fountain head of the nation's destiny. We lay our hands upon its throbbing heart. Never again shall we come so near having the destiny of a great nation in our own hands."17

But opportunity was not achievement. The role of the preacher in Confederate armies was neither clearly defined nor greatly respected. Chaplains had no official military rank, received poor pay and only a private's rations. To combat the "low repute" in which the post was held, ministers and many churches lobbied throughout the war for legislative improvement in the chaplain's situation, but their efforts met with only limited success. Most denominations supplemented meagre army salaries in order to encourage qualified men to serve, but many regiments and even brigades - perhaps as many as half-never had an official minister. In June 1861 Virginia Baptists decided to augment government efforts by employing colporteurs to distribute tracts and to discuss religious subjects with the men. Several Protestant denominations also sent itinerant civilian missionaries to the troops, and these preachers usually cooperated closely with official chaplains in the effort to spread the divine word to every part of the army. Denominational differences were all but forgotten in what became an ecumenical movement to bring Christ to the camp. Baptists preached without insisting on baptism as a requirement for the forgiveness of sin; Protestant soldiers flocked to services conducted by Catholic chaplains. Evangelist J. William Jones remarked that war had brought "a truce to denominational bickerings - there are no sectarian sermons preached and no sectarian tracts circulated, but all seem to work together to make men Christians . . .."18

three church members in the Old South were women; see Mathews, Religion in the Old South, 47; John E[llis]. Edwards, The Wounded Soldier (Raleigh, [186-]), 5 (sixth and seventh quotations). On adolescence and conversion see Carl W. Christensen, "Religious Conversion," Archives of General Psychiatry, IX (September 1963), 210.

${ }^{17}$ McDonnald, Address to Chaplains and Missionaries, 8 (first part of quotation), 13 (second part of quotation).

18 Jones, Christ in the Camp, 360, 365 (quotation); Southern Presbyterian, June 25, 1863; Southern Churchman, December 18, 1863; Biblical Recorder, December 9, 1863, February 5, 1862; T. Conn Bryan, ed., "Letters of Two Confederate Officers: William Thomas Conn and Charles Augustus Conn," Georgia Historical Quarterly, XLVI (June 1962), 177; Stephen 
In the fall of 1862 these religious labors began to bear fruit, as circumstances came to the aid of the southern churches. The timing of evangelical successes during the war offers important clues to the meaning of the conversion experience. By late 1862 many initial illusions had begun to disappear; after more than a year of "hard service," as one chaplain explained, "the romance of the soldier's life wore off, a more sober and serious mood seemed to prevail in the camps." Conscription had begun the previous spring, and by fall soldiers without the romantic zeal and optimism of the original volunteers had joined the ranks. Perhaps most significantly, however, revivals first broke out among troops retreating from Maryland after the Confederate loss at Antietam, which represented not only the first major southern defeat in the eastern theater but the bloodiest single battle day of American history as well. The experiences of slaughter and military failure surely had their impact in encouraging the "serious reflection and solemn resolve" that preceded evangelical commitment. There was great "eloquence" in the "din" and "carnage" of the field. "We are so much exposed," one soldier observed, as he

Cocke to Charles T. Quintard, April 25, 1863, and William Bennett to Charles T. Quintard, March 25, 1863, Charles Todd Quintard Papers (Duke); "The Office of Evangelist," Central Presbyterian, April 3, 1862; Joseph T. Durkin, ed., Confederate Chaplain: A War Journal of Rev. James B. Sheeran, . . . 14th Louisiana, C.S.A. (Milwaukee, 1960), 57; Confederate Baptist, May 20, 1863. Episcopalians and Presbyterians expressed some doubts about evangelical fervor but were for the most part won over by the revivals' power and effectiveness. See William S. Lacy to Bessie L. Dewey, September 23, 1863, Drury Lacy Papers (SHC); and Abner Crump Hopkins Diary, March 16, 1863, Abner Crump Hopkins Papers (Virginia Historical Society, Richmond). As one Episcopal paper rationalized, "anything is better than the quietness of moral death . . .." Southern Churchman, June 5, 1863. Some members of the more literalistic denominations indicated concern about the doctrinal compromises implicit in cooperation. See for example Biblical Recorder, July 30, 1862, December 9, 1863, January 16, 1864, and October 19, 1864. On hostility to chaplains see Confederate Baptist, November 4, 1863; and R. S. Webb to his mother, February 13, 1864, Webb Family Papers. On lobbying for improved status see for example Southern Christian Advocate, February 19, 1863; and Central Presbyterian, January 11, 1862. On chaplains generally see W. Harrison Daniel, "An Aspect of Church and State Relations in the Confederacy: Southern Protestantism and the Office of Army Chaplain," North Carolina Historical Review, XXXVI (January 1959), 47-71; Frank L. Hieronymus, "For Now and Forever: The Chaplains of the Confederate States Army" (unpublished Ph.D. dissertation, University of California, Los Angeles, 1964); Bell Irvin Wiley, “'Holy Joes' of the Sixties: A Study of Civil War Chaplains," Huntington Library Quarterly, XVI (May 1953), 287-304; Sidney J. Romero, "The Confederate Chaplain," Civil War History, I (June 1955), 127-40; Romero, Religion in the Rebel Ranks; James W. Silver, "The Confederate Preacher Goes to War," North Carolina Historical Review, XXXIII (October 1956), 499-509; Norton, Rebel Religion; Charles Frank Pitts, Chaplains in Gray: The Confederate Chaplains' Story (Nashville, 1957); Arthur Howard Noll, Doctor Quintard: Chaplain C.S.A. and Second Bishop of Tennessee (Sewanee, Tenn., 1905); Joseph Cross, Camp and Field: Papers from the Portfolio of an Army Chaplain (Macon, Ga., 1864); Donald E. Everett, ed., Chaplain Davis and Hood's Texas Brigade . . . (1863; rpt. ed., San Antonio, 1962); Randolph H. McKim, A Soldier's Recollections: Leaves from the Diary of a Young Confederate . . . (New York, 1921); A. D. Betts, Experiences of a Confederate Chaplain, 1861-1864, ed. by W. A. Betts (n.p., n.d.); Durkin, ed., Confederate Chaplain; Jones, Christ in the Camp; and Bennett, A Narrative of the Great Revival. 
explained why he had quit "light trashy novels" for the Bible, "we are likely to be called off at any moment."19

During the rest of the war the most dramatic outbursts of religious enthusiasm followed fierce and bloody battles-especially losses. The "great revival along the Rapidan" in the late summer and fall of 1863 swept through troops encamped for the first time since their retreat from Gettysburg. The pattern was clear to contemporary observers. As one army correspondent explained in 1863 to the Confederate Baptist, "There have been always among us, some pious men, but until that time nothing like a general revival or even seriousness. The regiment had just returned from the disastrous Pennsylvania expedition, and a few days before had the closest and most desperate encounter with the enemy that they had ever had. The minds of the men were fresh from scenes of danger and bloodshed and were forced thereby to contemplate eternity, and in many cases, to feel the necessity of preparation." In the West, Vicksburg and Chattanooga had a similar effect. Individual experiences of grace were closely connected to the wider search for God's favor implicit in the divine gift of military victory. As one recently converted soldier wrote in a letter home, he hoped the revival in his camp would bring "a great blessing nationally as well as Spiritually."20

Religion thrived, however, not just on growing personal and national insecurity, not just on individual and collective fear of the Yankees, but on anxieties related to social realities within the Confederate army itself. Chaplains, missionaries, and colporteurs had begun to make clear that rather than hinder military effectiveness, they could do a great deal to enhance it. Officers previously indifferent, if not openly hostile, to religion in the camps came to encourage piety and to provide spaces and occasions for the evangelization of their troops. "It is an interesting fact," observed Baptist preacher J. J. D. Renfroe in November 1863, "that most of our officers have undergone some change on the subject of

${ }^{19}$ Bennett, A Narrative of the Great Revival, 246 (first quotation); Jones, Christ in the Camp, 272 (second quotation); Religious Herald, August 21, 1862 (third quotation); Central Presbyterian, November 6, 1862; Religious Herald, October 23, 1862, November 27, 1862; Biblical Recorder, September 2, 1863; Camp Nineveh (Petersburg, Va., [186-]); Everett, ed., Chaplain Davis, 107; Addams to Dear Brother, January 5, 1863, William Miller McAllister Papers (Duke) (fourth quotation). On conversions after the Wilderness see Southern Christian Advocate, July 28, 1864. On Antietam see Stephen W. Sears, Landscape Turned Red: The Battle of Antietam (New Haven and New York, 1983). Wiley overlooks these 1862 outbursts but emphasizes the significance of Gettysburg in the 1863 revivals. Wiley, The Life of Johnny Reb, Chap. 10.

${ }^{20}$ Confederate Baptist, April 6, 1864 (first quotation); Mat[hew]. A[ndrew]. Dunn to Nora, August 22, 1864, in Weymouth T. Jordan, ed., "Mathew Andrew Dunn Letters," Journal of Mississippi History, I (April 1939), 110-26 (second quotation on p. 125); Jones, Christ in the Camp, 245; Religious Herald, September 3, 1863. 
chaplains. . . . when they first started out it made no difference with them what sort of man they had for chaplain, or whether they had any at all; but now you will not talk with an officer ten minutes about it until you will discover that he does not want a chaplain simply to 'hold service,' but he wants a man who will promote the religious good of his regiment. I have had irreligious officers to tell me that a good chaplain is worth more for the government of troops than any officer in a regiment." Colonel David Lang communicated his satisfaction that his chaplain's efforts in the fall of 1863 were "making good soldiers of some very trifling material." ${ }^{21}$

Despite the notable and inspiring exceptions of Robert E. Lee, Stonewall Jackson, and other pious commanders, army evangelism had its greatest impact among the common soldiers. Missionaries, chaplains, and even Jackson himself complained repeatedly of the religious indifference of the officers. The rhetoric of the Confederate revival, the themes of its sermons and its tracts, suggest one obvious explanation of why so many southern leaders encouraged piety among their troops while they remained largely aloof. "Irreligious colonels," the Religious Herald explained, "seek the cooperation of a good chaplain in their desire to render their regiment as efficient as possible." Religion promised significant assistance in the thorny problem of governing the frequently intractable Confederate troops. ${ }^{22}$

From the outset the Confederate army experienced great difficulties with discipline, for the southern soldier was most often a rural youth who had every expectation of becoming - if he was not already - an independent landholding farmer. Despite the uneven distribution of wealth and particularly of slaveownership in the prewar South, the common man ordinarily had no direct experience with political or social oppression, for he lived in a democratic political and social order where decentralization minimized perceptions of sharp stratification between planters and plain folk. The prevalent

${ }^{21}$ Confederate Baptist, November 4, 1863 (first quotation). See also Religious Herald, November 5, 1863, August 21, 1862; and David Lang to Cousin Annie, September 13, 1863, in Bertram H. Groene, ed., “Civil War Letters of Colonel David Lang," Florida Historical Quarterly, LIV (January 1976), 359 (second quotation). Cromwell's army was frequently cited as evidence of the military effectiveness of religion; see Religious Herald, July 31, 1862. Note the observation of one officer who felt that a town regiment was always twice as efficient as one from the country; cited in Horace H. Cunningham, Field Medical Services at the Battle of Manassas (Bull Run) (Athens, Ga., 1968), 25.

22 Jones, Christ in the Camp, 501, 465-66; Durkin, ed., Confederate Chaplain, 50-51; Confederate Baptist, May 16, 1863; Religious Herald, August 21, 1862 (quotation). On religion and officers see also Thomas Hart Law, July 20, 1863, Journal, Thomas Hart Law Papers (South Caroliniana Library); and William S. Lacy to Bessie L. Dewey, September 23, 1863, Lacy Papers. Other religious generals included Leonidas L. Polk, John B. Gordon, Daniel H. Hill, Ambrose P. Hill, John B. Hood, and Joseph E. Johnston. 
ideology of republicanism had encouraged rich and poor whites alike to cherish their "independence" and autonomy, emphasizing a sharp contrast between their status and that of enslaved blacks. But the army was to demand a hierarchy and a discipline that the prewar situation had not, even if practices such as election of officers might seem to symbolize the soldier's willing contractual surrender of control over his own life. Previously masterless men were compelled in the army to accept subordination for the first time, and many recruits complained bitterly about this change in expectations and circumstances. As one young soldier wrote home in the summer of 1861, "we are not lowd to go to the Shops without a permit and we are not lowd to miss a drill without a furlo sickness or permit, we are under tite rules you dont no how tite they are I wish I coul see you and then I could tell you what I thought of campt life it is very tite rules and confinen." ${ }^{23}$

Religion promised considerable assistance in easing this difficult transition. Élie Halévy, E. P. Thompson, and others have described the role of Methodism in the transformation of English workers into an industrial proletariat, and more recently Anthony F. C. Wallace has explored the influence of evangelical Protestantism upon laborers in nineteenth-century Pennsylvania textile mills. In the South of the 1860 s the role of religion was somewhat different, for young rural Confederates were going to war, not to the factories. But the requirements of industrialized work and industrialized warfare are alike in important ways - in their demand for new levels of discipline, regularity, and subordination. Daniel T. Rodgers has

23 James S. Beavers to Isham Sims Upchurch, July 2, 1861, Isham Sims Upchurch Papers (Duke) (quotation). On discipline see David Donald, "Died of Democracy," in David Donald, ed., Why the North Won the Civil War (Baton Rouge, 1960), 77-90; Everett, ed., Chaplain Davis, 150-51; also Jefferson Davis's call for greater discipline, quoted in the Confederate Baptist, November 12, 1862; and "Address of General D[aniel]. H[arvey]. Hill, Reunion of the Virginia Division Army of Northern Virginia Association," Southern Historical Society Papers, XIII (January-December 1885), 261. The Confederate army contained a significantly greater proportion of previously masterless men than did the northern army. By 1870 , when the first complete occupational census was taken, 60 to 70 percent of the northern labor force worked under masters. Agricultural areas of the North, and the white South generally, averaged well below this. Daniel T. Rodgers, The Work Ethic in Industrial America, 18501920 (Chicago and London, 1978), 37. See also David Montgomery, Beyond Equality: Labor and the Radical Republicans, 1862-1872 (New York, 1967), 30; and Eric Foner, Free Soil, Free Labor, Free Men: The Ideology of the Republican Party Before the Civil War (New York, 1970), 32. Both the less detailed 1860 census (which lacks complete occupational data) and data collected by Bell Wiley indicate marked prewar differentials as well. Also note that 20 percent of the Confederate army was made up of draftees and substitutes as compared with 8 percent of the Union forces; see McPherson, Ordeal By Fire, 359, 182. On the devotion of the southern common people to their personal independence see J. Mills Thornton III, Politics and Power in a Slave Society: Alabama, 1800-1860 (Baton Rouge and London, 1978); and Steven Hahn, The Roots of Southern Populism: Yeoman Farmers and the Transformation of the Georgia Upcountry, 1850-1890 (New York and Oxford, 1983). 
described a process of "labor commitment - . . by which new industrial employees adjusted deeply set rural loyalties and work habits to the disrupting demands of factory labor." In their identity shift from farmers to soldiers, young southerners needed to make analogous changes in internal values and expectations. A soldier "must be trained," insisted the Religious Herald, "and willing to submit to thorough training . . . . There is a moral requirement as important as the material one - an inward man as indispensable as the outward one ...." Religious conversion and commitment could serve as the vehicle accelerating and facilitating this necessary personal transformation. Both southern military and religious leaders recognized that Evangelicalism could contribute to internalizing discipline and enhancing the efficiency of the Confederate soldier; the church could help to mold disorganized recruits into an effective fighting force. "A spirit of subordination and a faithful discharge of duty," the Biblical Recorder summarized, "are [as] essential to the good soldier" as they are to the good Christian. ${ }^{24}$

The term "efficiency" appeared again and again in evangelical rhetoric. The Christian soldier would be an efficient soldier because he would not be afraid to die; he would be obedient and well disciplined because he would understand the divine origin of earthly duty. One army chaplain offered a striking illustration of the "military power of religion. In a brigade of five regiments, where there has recently been a glorious revival, two of the regiments, which had not shared in the revival, broke, while the three which had been thus blessed stood firm . . . . A missionary of the Army of Tennessee made an even more dramatic claim. "Preaching," he asserted, had "corrected" one of "the greatest evils of our army, in a military point

${ }^{24}$ E. P. Thompson, The Making of the English Working Class (New York, 1963); Thompson, "Time, Work-Discipline, and Industrial Capitalism," Past \& Present, XXXVIII (December 1967), 56-97; Anthony F. C. Wallace, Rockdale: The Growth of an American Village in the Early Industrial Revolution . . . (New York, 1978); Élie Halévy, Histoire du peuple anglais au XIXe siecle (Paris, 1913). Daniel T. Rodgers, "Tradition, Modernity, and the American Industrial Worker: Reflections and Critique," Journal of Interdisciplinary History, VII (Spring 1977), 656 (first quotation); Herbert G. Gutman, Work, Culture, and Society in Industrializing America: Essays in American Working-Class and Social History (New York, 1976); Bruce Tucker, "Class and Culture in Recent Anglo-American Religious Historiography: A Review Essay," Labour/Le Travailleur, VI (Autumn 1980), 159-69; Religious Herald, July 31, 1862 (second quotation); Biblical Recorder, July 10, 1861 (third quotation). See also Central Presbyterian, February 6, 1862; Christian Observer, June 30, 1864; Army and Navy Messenger, May 1, 1863. On the weakness of the work ethic in the South see C. Vann Woodward, "The Southern Ethic in a Puritan World," Chap. 1, in American Counterpoint: Slavery and Racism in the North-South Dialogue (Boston and Toronto, 1971), especially 29 and 42 . As E. P. Thompson has noted the relevance of timepieces to industrial work, David Landes has similarly related their development and dissemination to industrialized warfare. David S. Landes, Revolution in Time: Clocks and the Making of the Modern World (Cambridge, Mass., and London, 1983). 
of view . . . - that of straggling." The servant of God, he explained, learned that he must execute all earthly as well as all spiritual obligations "conscientiously," and that meant keeping up with your regiment even if you were ill or had no shoes. A colonel of the South Carolina Volunteers emphasized the point when he congratulated a colporteur on the usefulness of his tracts, which he found "of incalculable service in encouraging the soldier to a continuation of his hard duties, and making him feel contented with his lot."25 The Reverend R. N. Sledd no doubt won similar approval from Confederate military leaders when he insisted to a congregation of common soldiers about to depart for war that "it is . . . not only wise, but necessary to your efficiency, that for the time you surrender your will to that of your officers, . . . This lesson of submission to control is a difficult one for many to learn; but until you have completely mastered it, . . . you are not prepared to behave yourself the most valiantly and the most efficiently in the field of conflict." Significantly, religious leaders stressed the profitable management of time as well as the adoption of regular personal habits, and often chose the bourgeois language of commerce and the marketplace to emphasize the productive uses of religion. A correspondent to the Religious Herald suggested in 1863 that chaplains on the field make themselves easily identifiable by wearing badges emblazoned with the epigraph, "Godliness is profitable unto all." Another article reported an imaginary dialogue between an officer and a recently converted private who assured his superior, "II used to neglect your business; now I perform it diligently'."26

But the virtues religion inculcated did not just appear on the battlefield. Evangelicalism also sought to ease the conflict over appropriate values and behavior that was disturbing many Confederate camps. Soldiers who had lived in isolated circumstances in the overwhelmingly rural South had found little necessity to adjust to the lifestyles of other groups. Many complaints in their wartime diaries

${ }^{25} \mathrm{~W} . \mathrm{H}$. Christian, The Importance of a Soldier Becoming a Christian (Richmond, [186-]), 3; Jones, Christ in the Camp, 380-81 (first quotation); North Carolina Presbyterian, August 4, 1862; Confederate Baptist, July 6, 1864 (second quotation), May 16, 1863 (third quotation). On the religious cure for desertion see John Paris, A Sermon: Preached Before Brig. -Gen. Hoke's Brigade, . . . Upon the Death of Twenty-Two Men . . . Executed in the Presence of the Brigade for the Crime of Desertion (Greensborough, N. C., 1864), 12. On the severe military problem presented by persistent straggling see The War of the Rebellion: $A$ Compilation of the Official Records of the Union and Confederate Armies (70 vols. in 128; Washington, 1880-1901), Ser. I, Vol. XIX, Pt. 1, 1026; and Worsham, One of Jackson's Foot Cavalry, 151.

${ }^{26}$ R. N. Sledd, A Sermon; Delivered in the Market Street M. E. Church, Petersburg, Va., Before the Confederate Cadets, on the Occasion of Their Departure for the Seat of War, Sunday, Sept. 22d, 1861 (Petersburg, 1861), 14 (first quotation); Religious Herald, April 23, 1863 (second quotation), June 11, 1863 (third quotation). 
and letters sound very much like the earlier reactions of genteel Yankees first confronting the squalid realities of life among the lowly in the urban North. Confederate army camps played a role analogous to that of northern cities in juxtaposing classes and cultures in what was to many a new and alarming propinquity. "One of my greatest annoyances," a Mississippian wrote to his wife, "is my proximity to one tent of the Co[mpany]. next [to] me . . . in which are 9 or 10 [of] the most vile, obscene blackguards that could be raked up this side [of] the bad place, outside of a jail or penitentiary. From early morn to dewey eve there is one uninterrupted flow of the dirtiest talk I ever heard in my life. . . . those fellows have "had no raising'." 27

The nature and sources of this social conflict should not be oversimplified; the social location and meaning of southern Evangelicalism is complex. Part of the controversy in army camps was a lingering hostility among some of the southern gentry towards Evangelicalism, an antagonism that had persisted since the Great Awakening of the mid-eighteenth century. In 1865, for example, the Baptist Religious Herald referred openly and distressfully to the "causes which have tended to produce in men of taste an aversion to evangelical religion." A century before the Civil War, as Rhys Isaac has argued, the categories of class and religious identity were quite clear. The gentry overwhelmingly opposed the restrictions on their aristocratic pleasures that the pious sought to impose. But by the 1860 s the class location of Evangelicalism - and especially of the refined behavior that it encouraged - was more nearly reversed. As Bertram Wyatt-Brown, Donald G. Mathews, and others have contended, "the mission cause" made "good headway among the privileged ranks of southerners between 1820 and 1840." And even those of the elite who were not themselves converted often encouraged and supported the social influence of the evangelical churches. Although the controversies over lifestyle and personal behavior in southern army camps should not be seen as exclusively the effort of an upper stratum to impose its standards on a lower, this concern was certainly a significant element in the conflict. Aristocratic Confederates who themselves swore, drank, or duelled also incurred the wrath of the evangelical leaders in the army. But by far the most prominent target of reform efforts were the lower orders, the same social groups that

${ }^{27}$ T. J. Koger, June 22, 1862, quoted in John K. Bettersworth, ed., Mississippi in the Confederacy: As They Saw It (Baton Rouge, 1961), 346. See also the volunteer cavalry colonel who early in the war resigned because of "the uncontrollable wickedness of soldiers in camp." John N. Waddel, Memorials of Academic Life: Being an Historical Sketch of the Waddel Family. . . (Richmond, 1891), 398; A. Curtis to Matthias Murray Marshall, December 20, 1862, Matthias Murray Marshall Papers (Duke); Samuel P. Lockhart to Emeline Lockhart, May 11, 1862, July 27, 1862, Browning Papers; Unidentified to Dear Willie on back of Dr. G. McAllister to Dear Clara, October 26, 1861, McAllister Papers. 
had been the objects of intensive prewar southern missionary efforts. These were the individuals the army evangelists encouraged to behave more decorously, to wash regularly, to make prudent use of time, and, indicating the presence in this group of many illiterates, to learn to read. ${ }^{28}$

In the army the evangelical cause took on a new urgency because of the "great trial" imposed on numbers of refined southerners who found themselves required to tent next to "such abounding wickedness" as was represented by some of their comrades. Separated before the war by the decentralized, overwhelmingly rural nature of southern life, privileged and less privileged whites came to know each other in new and unsettling ways within the Confederate camps. And with this knowledge came not the rapprochement of different social groups so often hailed as the outcome of the English experience in the trenches of World War I. Instead, in a South that had throughout the antebellum period stressed the republican equality of all white men, this wartime experience brought an emerging awareness of class. "Cannot something be done to lessen the unnatural distance that is gradually and rapidly creeping in between officers and men?" one tract demanded. The Soldier's Paper worried in similar terms, "Let not our private soldiers feel that they have ceased to be men because they are soldiers. Let them not imagine that they are degraded to mere machines because they are fighting in the ranks . . . let them feel that they still have friends in their officers." A correspondent in the Confederate Baptist in 1863 was more explicit still in a discussion of the plight of the common fighting man oppressed by his superiors. "ClASSES -," he reflected. "We were struck with a remark made to us by a private in the army. He said, "before the war, there were only white men and negroes among us; now there are white men, negroes and soldiers'." It could not but have been chillingly symbolic for the troops marched out in June 1862 to witness

\footnotetext{
${ }^{28}$ Religious Herald, February 23, 1865 (first quotation); Rhys Isaac, The Transformation of Virginia, 1740-1790 (Chapel Hill, 1982); Bertram Wyatt-Brown, "The Antimission Movement in the Jacksonian South: A Study in Regional Folk Culture," Journal of Southern History, XXXVI (November 1970), 522 (second quotation). In this article Wyatt-Brown details the prewar resistance among many of the southern lower orders to attempts to impose evangelical order from above. On class divisions in antebellum southern religion see also Wayne Flynt, "One in the Spirit, Many in the Flesh: Southern Evangelicals," in David Edwin Harrell, Jr., ed., Varieties of Southern Evangelicalism (Macon, Ga., 1981), 25. See Confederate Baptist diatribes against duelling, December 3,1862, and April 29, 1863; on reading see for example Jordan, ed., "Mathew Andrew Dunn Letters," 116; and Jones, Christ in the Camp, 363, 500. On hostility to Evangelicalism see Folmar, ed., From That Terrible Field, 13; Wiley, "Holy Joes'," 291, 294; The Christian Sergeant (Richmond, [186-]). On similar complexity in the relationship between Evangelicalism and class in the North see Paul E. Johnson, A Shopkeeper's Millenium: Society and Revivals in Rochester, New York, 1815-1837 (New York, 1978).
} 
the punishment of army deserters with thirty-nine lashes and branding on the cheek - a characteristic form of correction for runaway slaves throughout the antebellum period. White men previously above corporal punishment seemed as soldiers to occupy a new status in which even the most cherished distinctions between freeman and black slave were fast disappearing. As the Confederate Baptist protested in 1863, "That any officer of the Confederate army should inflict upon a fellow soldier, a punishment which is peculiar to slaves, is enough to make us blush for our country. Is the poor man a negro, and is he fighting only for the privilege of having a different master?" 29

The social significance of the revival impulse is perhaps most strikingly revealed to a twentieth-century observer by the unexpected centrality and importance of the evangelical campaign against profanity, which one chaplain hailed as "the national sin." Although one response to such a curious claim might be admiration for the level of virtue such a minor indictment implies, evangelical preoccupation with swearing deserves fuller explanation. By the mid-nineteenth century public profanity was becoming largely a class sin, found most often, as one tract explained, among the "common" and the "ill bred." In an 1860 analysis of social classes in the South, for example, native Alabamian Daniel R. Hundley defined "low, vulgar and obscene" speech as characteristic of one particular element of the region's lower orders. ${ }^{30}$ But what might now be regarded as the seemingly harmless "profanity of the privates" attracted enormous attention from Evangelicals. Swearing, they declared repeatedly, was dangerous because it was a "useless sin." Unlike gluttony, venality, or

${ }^{29}$ Religious Herald, quoted in E. M. Boswell, "Rebel Religion," Civil War Times Illustrated, XI (October 1972), 28 (first and second quoted phrases); $A$ Kind Word to the Officers of our Army (Charleston, [186-]), 2 (third quotation); Soldier's Paper, February 15, 1864 (fourth quotation); Confederate Baptist, October 21, 1863 (fifth quotation); Addams to Dear Brother, June 12, 1862, McAllister Papers; Confederate Baptist, April 8, 1863 (sixth quotation). For an outstanding treatment of the role of class in the Confederacy see Armstead Louis Robinson, "Day of Jubilo: Civil War and the Demise of Slavery in the Mississippi Valley, 1861-65" (unpublished Ph.D. dissertation, University of Rochester, 1977).

30 Swearing (Raleigh, [186-]), 2 (first quotation); the same phrase appears also in [Jabez Lamar Monroe Curry], Swearing (Raleigh, [186-]), 2; [Brockenbrough], A Mother's Parting Words, 5 (second quotation); D[aniel]. R. Hundley, Social Relations in Our Southern States (1860; rpt. ed., Baton Rouge, 1979), 226, 239-40 (third quoted phrase). Also see literary treatments of antebellum southern language in which swearing is restricted to a particular, often morally depraved segment of the lower class, or, as in William Gilmore Simms's Woodcraft, soldiers. Simms, Woodcraft, or Hawks about the Dovecote: A Story of the South at the Close of the Revolution (1854; rpt. ed., New York, 1961). See also A. B. Longstreet, "Georgia Theatrics," and "The Fight," in Georgia Scenes: Characters, Incidents . . . in the First Half Century of the Republic (1835; rpt. ed., Gloucester, Mass., 1970); Merrill Maguire Skaggs, The Folk of Southern Fiction (Athens, Ga., 1972), 23; and Shields Mcllwaine, The Southern Poor-White from Lubberland to Tobacco Road (Norman, 1939), 50. 
lust, it had no rational objective. The swearer risked damnation for no purpose. "You commit the utter folly of . . . ruining your souls, for nothing at all!" To swear was "to incur guilt, without delight." In an age and within a religious movement increasingly dedicated to the advancement of utilitarian values, swearing represented an "irrational," "unprofitable," inefficient vice; it simply did not "pay." In its purposeless affront to piety it seemed to carry with it a dangerous "spirit of rebellion against conscience, society and God." Swearing was "disinterested sin-sin committed only from the love of sin." It was a direct and overt attack on religion and social order rather than a sin committed out of moral weakness in the face of irresistible temptation. A quintessential embodiment of loss of control and rejection of deference, profanity became a symbolic as much as a substantive enemy of the army revivals. ${ }^{31}$

In writing of World War I, Eric J. Leed has argued that there occurred a "militarized proletarianization" of European soldiers. Certainly no such dramatic transformation took place in the Confederate South, for this first modern war fell far short of the 1914 conflict in its demands for hierarchy, routine, and control. Nevertheless, Leed's observation, combined with the rhetoric of Confederate army religion, cannot help but draw attention to the new work patterns warfare imposed and to the loss of autonomy and independence it implied for the average southerner. As one Virginia private tellingly observed, "A soldier in the ranks is like a piece of machinery-he moves and acts as commanded." Even though his salary was often not even paid, the Confederate soldier was in most cases undergoing his first experience as a wage laborer subordinate to the direction of his employer. When at the end of the war the Nation called for the North to "turn the slothful, shiftless Southern world upside down," little

${ }^{31}$ Sylvanus Landrum, The Battle is God's . . . (Savannah, 1863), 12 (first quoted phrase); R[obert]. L[ewis]. Dabney, Swear Not (Petersburg, Va., 1863), 1 (second quoted phrase and third quotation); Southern Christian Advocate, February 5, 1863 (fourth quoted phrase); Profane Swearing (Charlotte, N. C., 1864), 3 (fifth quoted word); J[eremiah]. B[ell]. Jeter, Don't Swear! (Raleigh, [186-]), 1 (sixth quoted word); Why Do You Do It? (Richmond, [186-]), 1 (seventh quoted word); J. N. Andrews, Why Do You Swear? (Raleigh, [186-]), 6 (eighth quotation); J. C. Mitchell, A Sermon Delivered in the Government Street Church (Mobile, 1861), 20 (ninth quoted phrase). See also The Bold Blasphemer. A Narrative of Facts (Richmond, [186-]); B[enjamin]. M[organ]. Palmer, National Responsibility Before God . . . (New Orleans, 1861); Sam'l Barnett, The Tongue (Richmond, [186-]); The Silly Fish (Columbia, S. C., [186-]); and "Profane Swearing," Biblical Recorder, August 20, 1862. On the social role of swearing see K. C. Phillipps, Language and Class in Victorian England (Oxford and New York, 1984), 54; Robert Graves, Lars Porsena: Or the Future of Swearing and Improper Language (New York, 1927), 37n; Ashley Montagu, The Anatomy of Swearing (New York, 1967), 224, 226, 237; Henry Cecil Wyld, A History of Modern Colloquial English (1920; rpt. ed., Oxford, 1936), 386; Eric Partridge, Words at War, Words at Peace: Essays on Language in General and Particular Words (1948; rpt. ed., Freeport, N. Y., 1970). 
would editor E. L. Godkin have guessed that the leaders of the Confederate army and churches had already been acting as his unwitting allies. For four years they had struggled-albeit with uncertain success - to teach the southern soldier the very same values of training, regularity, and industry that Godkin hoped northern victory might now impose. ${ }^{32}$

Yet such a view of the role of Confederate religion-as manipulative and hegemonic - is partial and one-dimensional. Recent scholarly work has justly insisted that monolithic emphasis on the aspects of social control within evangelicalism must not distort its larger meaning or impugn the authenticity of revivalists' piety and sacred commitment by casting them simply as conspirators seeking to enhance their own social power. Most advocates of the order and discipline central to the revivalistic impulse sincerely believed that their goals were above all to fulfill God's design and only secondarily to serve the needs of men. The perceptions of the common Confederate soldiers who were the targets of army revivalists' efforts is less clear. Certainly the impact of the evangelical message among the troops was profound, as the large number of conversions attests. And many of these converts readily accepted the notion of a regenerate life as one of discipline and self-control, for soldiers frequently wrote home that revivals had made it impossible to find a cardplayer or a profane swearer in the regiment. It seems likely, however, that the cynicism of some reductionist twentieth-century social control historians may have been shared by at least some nineteenth-century soldiers. The suspicion and hostility toward evangelical hegemony expressed by the plain folk who participated in the antimission movement in the prewar South had not, in all probability, entirely disappeared, even though there is scant surviving evidence of its existence in the Confederate army. The revivals could not in any case have completely succeeded in transforming southern soldiers into a tightly disciplined fighting force, for complaints about insubordination continued throughout the war and even increased as the desertion rate rose dramatically in 1864 and $1865 . .^{33}$

32 Eric J. Leed, No Man's Land: Combat \& Identity in World War I (Cambridge, Eng., and other cities, 1979), 94 (first quoted phrase); John O. Casler, Four Years in the Stonewall Brigade, edited by James I. Robertson, Jr. (1893; rpt. ed., Dayton, Ohio, 1971), 291 (second quotation); Rodgers, The Work Ethic in Industrial America, 32 (third quotation); The Sentinel (Petersburg, Va., 1861), 1.

${ }^{33}$ See Adam to Harriet C. Lewis, November 1, 1864, Harriet C. Lewis Papers (Duke); James N. Riddle to Dear Sisters, August 11, 1863, James N. Riddle Papers, ibid. On social control and religion see Lois W. Banner, "Religious Benevolence as Social Control: A Critique of an Interpretation," Journal of American History, LX (June 1973), 23-41. On opposition to Evangelicalism see Wyatt-Brown, "Antimission Movement"; and Flynt, "One in the Spirit, Many in the Flesh," 23-44. 
Common soldiers may well have ignored much of the rhetoric of control in tracts and sermons to appropriate from the evangelical message truths that they found more meaningful. The notion of a disciplined and deferential Christian soldier undoubtedly had a greater appeal to religious and military leaders than to the common fighting man instructed that it was his "business . . to die." Yet Evangelicalism met important needs for the soldiers themselves as well as for their military masters. Like religion among black slaves or working-class Methodists, army evangelism did what E. P. Thompson has described as a "double service," appealing in different ways both to the powerful and to the powerless. In the Old South the Christianity preached by masters to their bondsmen was quite different from that embraced by the slaves. ${ }^{34}$

Similarly, common Confederate soldiers used religion in their own ways, focusing on the promise of salvation from death as well as upon the reality of an evangelical community that recreated some of the ideals of a lost prewar world. The experience of conversion served as the basis for a shared equality of believers and an Arminian notion of ultimate self-determination that in profound ways replicated the antebellum republican order that military hierarchy and command had obliterated. There was, as the Religious Herald observed in 1863 , a sense of real "homogeneity and fellow-feeling" within the brotherhood of believers. ${ }^{35}$ The comradeship of the regenerate encouraged as well the group solidarity that modern military analysts have identified as critical to the maintenance of morale. Converts formed Christian Associations within their brigades and regiments to assume communal responsibility for evangelical discipline, and, in the words of the constitution of one such organization, "to throw as many strengthening influences around the weak . . . as it is possible to do ...." The associations ran Bible and reading classes, established camp libraries of tracts and religious newspapers, but, perhaps most significantly, confronted the fear of death-and of dying abandoned and alone - that haunted so many soldiers. The believers of the Seventh Virginia Infantry covenanted, for example, to "care specially for each other in all bodily or mental suffering, to show each other respect in case of death. . . ." In practice this usually meant that association members would try to identify comrades disabled on the field of battle in order to provide them either with medi-

${ }^{34}$ The Sentinel, 1 (first quotation); Thompson, The Making of the English Working Class, 354-55; Eugene D. Genovese, Roll, Jordan, Roll: The World the Slaves Made (New York, 1974).

${ }^{35}$ For an excellent portrait of the quality of the evangelical community see Isaac, The Transformation of Virginia, 161-72; Religious Herald, September 3, 1863. 
cal care or with Christian burial. ${ }^{36}$

On a more individual level, evangelical religion provided psychological reassurance to southern soldiers struggling with the daily threat of personal annihilation. In its Christian promise of salvation and eternal life, conversion offered a special sort of consolation to the embattled Confederate. In striking ways accounts of camp conversions parallel descriptions of what in World Wars I and II was first known as "shell shock," then as "combat exhaustion" or "combat stress." Shaking, loss of speech, paralysis of limbs, uncontrolled weeping, and severe emotional outbursts often appeared among twentieth-century soldiers when they reached safety after military action. Similar behavior characterized many Confederate converts who found Christ in the emotion-filled revival meetings held in the intervals between Civil War battles. The fiercest encounters brought the largest harvests of souls, just as the most desperate fighting of World Wars I and II yielded the highest incidence of combat stress. These similarities in nineteenth- and twentieth-century soldiers' responses suggest that analogous psychological processes might well have been involved. ${ }^{37}$

${ }^{36}$ On the importance of the primary group in battle see S. L. A. Marshall, Men Against Fire: The Problem of Battle Command in Future War (New York, 1947); Richard A. Gabriel and Paul L. Savage, Crisis in Command: Mismanagement in the Army (New York, 1978); and Anthony Kellett, Combat Motivation: The Behavior of Soldiers in Battle (Boston, 1982). For a sensitive consideration of the place of religion in another army see Charles Royster, $A$ Revolutionary People at War: The Continental Army and American Character, 1775-1783 (Chapel Hill, 1979), 13-23. Constitution, By-Laws, and Catalogue of Members of the Christian Association of the Stonewall Brigade (Richmond, 1864), 2 (first quotation); Religious Herald, June 4, 1863 (second quotation). See also Edmund Cody Burnett, ed., "Letters of a Confederate Surgeon: Dr. Abner Embry McGarity, 1862-1865," Georgia Historical Quarterly, XXIX (September 1945), 182-83; W. Harrison Daniel, "The Christian Association: A Religious Society in the Army of Northern Virginia," Virginia Magazine of History and Biography, LXIX (January 1961), 95-96; Daniel, "The Southern Baptists in the Confederacy," Civil War History, VI (December 1960), 397; Robert Emory Park, "War Diary of Capt. Robert Emory Park, Twelfth Alabama Regiment. January 28th, 1863-January 27th, 1864," Southern Historical Society Papers, XXVI (January-December 1898), 22; Jesse M. Frank to K. M. Frank, April 16, 1864, Alexander Frank Papers (Duke); Prim, "Born Again in the Trenches," 52. Religion also no doubt benefited from soldiers' close personal ties. See Rodney Stark and William Sims Bainbridge, "Networks of Faith: Interpersonal Bonds and Recruitment to Cults and Sects," American Journal of Sociology, LXXXV (May 1980), 1376-95; John Lofland and Rodney Stark, "Becoming a World-Saver: A Theory of Conversion to a Deviant Perspective," American Sociological Review, XXX (December 1965), 862-75.

${ }^{37}$ Leo H. Bartemeier, Lawrence S. Kubie, Karl A. Menninger, John Romano, and John C. Whitehorn, "Combat Exhaustion, Part I," Journal of Nervous and Mental Disease, CIV (October 1946), 358-89; "Part II," ibid. (November 1946), 489-525; Jones, Christ in the Camp, 281; North Carolina Presbyterian, September 20, 1862; Central Presbyterian, September 24, 1863; Soldier's Visitor, February 1864; Biblical Recorder, December 10, 1862; Prim, "Born Again in the Trenches," 40. See also William Sargant, Battle for the Mind: A Physiology of Conversion and Brain-Washing (Garden City, N. Y., 1957). A study of posttraumatic stress in Vietnam soldiers estimates that half of all veterans suffer from the syndrome and that stress disorders existed unrecognized in combat veterans well before World 
Twentieth-century scholars have often commented on the seeming failure of the Civil War soldier to grapple with the emotional significance of his experience. "Much in the Civil War was to be forgotten," Marcus Cunliffe has observed. "Involvement in it was intense yet oddly superficial." Unlike World War I, which yielded its Wilfred Owen, its Siegfried Sassoon, its Ernest Hemingway, the Civil War remained in a real sense unwritten, its horrors, if not unnoticed, at least denied. Yet in their own way and in their own particular idiom, Confederate soldiers were just as expressive as their World War I counterparts. Southerners were very articulate, for example, about their inability to portray what they had witnessed. After his first battle in 1861 one infantryman wrote home, "I have not power to describe the scene. It beggars all description." Kate Cumming, working as a nurse in a military hospital, commented even more tellingly on the inability of all those around her to communicate their experiences: "Nothing that I had ever heard or read had given me the faintest idea of the horrors witnessed here. I do not think that words are in our vocabulary expressive enough to present to the mind the realities of that sad scene." 38

The language of post-Freudian self-scrutiny used by World War I participants was not available to Civil War soldiers. But their silences are eloquent. Their speechlessness was part of a process of numbing, of the denial that is a widespread human response to stress. "We hurry," one soldier wrote, "through the dreadful task apparently unconscious of its demoralizing influences and destructive effects." The war, another confirmed, "is calculated to harden the softest heart." The majority came to act as "unconcerned as if it were hogs dying around them." A correspondent writing to the Religious Herald in 1862 understood well, however, "the true fountain" of this apparent indifference. Soldiers' unconcern, he explained, was "the result of an effort to banish, not to master, the fear of death. . . . the expedient of the ostrich [who acts] . . . . as though refusing to look on a peril were to escape from it." ${ }^{39}$

War I, when they first drew sustained attention. Herbert Hendin and Ann Pollinger Haas, Wounds of War: The Psychological Aftermath of Combat in Vietnam (New York, 1984), 6, 9.

${ }^{38}$ Marcus Cunliffe, Soldiers \& Civilians: The Martial Spirit in America, 1775-1865 (Boston, 1968), 435 (first quotation); Luvaas, The Military Legacy of the Civil War; Daniel Aaron, The Unwritten War: American Writers and the Civil War (New York, 1973); Thomas C. Leonard, Above the Battle: War Making in America from Appomattox to Versailles (New York, 1978). See also Paul Fussell, The Great War and Modern Memory (New York and London, 1975). Casler, Four Years in the Stonewall Brigade, 37 (second quotation); Kate Cumming, Kate: The Journal of a Confederate Nurse, edited by Richard Barksdale Harwell (1866; rpt. ed., Baton Rouge, 1959), 13-14 (third quotation). On numbness see also Obstacles to Conversion (Petersburg, Va., [186-]), 2-3.

${ }^{39}$ On indifference see the first page of The Soldiers' Almanac (Richmond, 1863), 9: "WARNING TO SOLDIERS. Guard against unfeeling recklessness. By unfamiliarity with scenes of vio- 
Modern-day analysts of combat stress point out, however, that such denial has its limits, that numbness and indifference can only be retained for so long. Eventually extreme stress results in the appearance of symptoms in virtually everyone. Often denial begins to be interrupted by what psychiatrists call "intrusions," nightmares or irrepressible and unwelcome daytime visions of stress-producing events. One Confederate soldier who had previously told his wife that he had found the battle of Shiloh indescribable wrote again several weeks later, "I've had great and exciting times at night with my dreams since the battle; some of them are tragedies and frighten me more than ever the fight did when I was awake . . . ." Another soldier was obviously more profoundly affected, for, as a friend described him, he began reliving battles in his everyday life. "He became more and more alarmed, and, at last, became so powerfully excited - to use his own words - he felt as if some one was after him with a bayonet, and soon found himself almost in a run, as he moved backwards and forwards in his beat."40

Many psychiatrists believe that reliving stress-producing experiences in this way serves to work through and eventually to resolve material repressed in the denial phase. The appearance of intrusions, therefore, signals the emergence of overt conflict that, even though profoundly disruptive, may ultimately enable an individual to cope with and to transcend a traumatic experience. Revivals often explic-

lence and death, soldiers often become apparently indifferent to suffering and anguish, and appear to be destitute of the ordinary sensibilities of our humanity." See also William L. Nugent to his wife, September 7, 1863, in Bettersworth, ed., Mississippi in the Confederacy, 354 (first quotation); Dunn to his wife, October 13, 1863, in Jordan, ed., "Mathew Andrew Dunn Letters," 112 (second quotation); H[ugh]. H[arris]. Robison to his wife, November 11, 1861 , in Weymouth T. Jordan, ed., "Hugh Harris Robison Letters," Journal of Mississippi History, I (January 1939), 54 (third quotation); Religious Herald, July 24, 1862 (fourth quotation), See also N. M. Osborne, Jr., to my dear Aunt, June 28, 1863, Elizabeth Moorman Smithson Papers (Duke).

${ }^{40}$ On combat stress see Mardi Jon Horowitz, Stress Response Syndromes (New York, 1976); Norman Q. Brill, "Gross Stress Reaction. II: Traumatic War Neurosis," in Alfred M. Freedman and Harold I. Kaplan, eds., Comprehensive Textbook of Psychiatry (Baltimore, 1967), 1031-35; Peter G. Bourne, Men, Stress, and Vietnam (Boston, 1970); Roy R. Grinker and John P. Spiegel, Men Under Stress (Philadelphia, 1945); Abram Kardiner and Herbert Spiegel, War Stress and Neurotic Illness (New York and London, 1947); Nolan D. C. Lewis and Bernice Engle, Wartime Psychiatry: A Compendium of the International Literature (New York, 1954); E. E. Southard, Shell-Shock and Other Neuropsychiatric Problems . . . (Boston, 1919); Albert Deutsch, "Military Psychiatry: The Civil War, 1861-1865," in American Psychiatric Association, One Hundred Years of American Psychiatry (New York, 1944), 36784; Peter Watson, War on the Mind: The Military Uses and Abuses of Psychology (New York, 1978). Folmar, ed., From That Terrible Field, 60 (first quotation); and Camp Nineveh, 4 (second quotation). See also Jones, Christ in the Camp, 289, and for a description of symptoms of "congestion of the brain" in a fearful soldier, James K. Street to My Dear Ninnie, May 8, 1863, James K. and Melinda East (Pace) Street Papers (SHC). See also Stephen Cocke to Charles T. Quintard, April 25, 1862, Quintard Papers. 
itly encouraged such intrusions and exacerbated internal tension in the effort to induce the religious conversion that would dissolve all stress in the promise of divine salvation. In order to shake soldiers' personal defenses, preachers and tracts insisted, "Death stares you in the face. The next battle may be your last." The soldier, one revivalist explained, had to be "forced to feel how frail and uncertain is life." The crisis was unavoidable; numbness and denial could be no real or lasting protection. In "the GREAT CONSCRIPTION there is no discharge . . . Are you ready to take your place with them who will have the victory? . . . Or will your place be in that vast division of death's army, which shall assemble only to be defeated, accursed and punished forever?"41

Significantly, the rhetoric of camp sermons was often designed to encourage a metaphorical reliving of battlefield experiences by casting religion as the equivalent of military conflict. Exhorters focused overwhelmingly on the issue of salvation and its frightening alternative, thus calling forth the feelings associated with the life-and-death struggle that soldiers actually confronted each day. Preachers manipulated already existing fear, stressing the nearness of death and its terrors for the unconverted. But at the same time that revivalists exacerbated the tension and helplessness soldiers felt in the face of battle, they emphasized that the men did retain a dimension of choice; even amidst the barrage of bullets, they could decide for God. As one tract demanded of those who had not yet exercised this option, Why Will You Die? Death, its author implied, was a matter of personal will and could be consciously rejected in favor of eternal life. Just as the common soldier concerned about social issues of mastery and subordination within army life could have the symbolic comfort of electing his own captain, so he might psychologically escape from his sense of victimization by choosing Christ as the "Captain of [his] . . . salvation." He might transcend the ultimate and profound loss of control over his destiny that battle involved by making an existential commitment, by enlisting as a Christian soldier under the "banner of the Cross." The decision for Christ restored the illusion of free will. And with the return of a sense of control often comes, as contemporary psychiatrists have observed, the ability once again to cope. ${ }^{42}$

${ }^{41}$ Confederate Baptist, June 17, 1863 (first quotation); Religious Herald, March 20, 1862 (second quotation); Biblical Recorder, October 8, 1862 (third quotation).

42 Why Will You Die? (Petersburg, Va., [186-]); and A. M. Poindexter, Why Will Ye Die? (Raleigh, [186-]); E[dwin]. T[heodore]. Winkler, Duties of the Citizen Soldier. A Sermon ... Before the Moultrie Guards (Charleston, 1861), 14 (first quotation); [Brockenbrough], Mother's Parting Words, 2 (second quoted phrase). J[ohn]. C[owper]. Granbery, An Address to the Soldiers of the Southern Armies (Raleigh, [186-]), 8; Are You Prepared? (Raleigh, [186-]), 1. On the role of loss of control in inducing stress see Horowitz, Stress Response Syndromes. 
Ultimately, revivalists insisted, this was not a war of North against South, but one of goodness versus evil, of God against Satan. Evangelical rhetoric invited soldiers to relive the emotions of the battlefield, to express the resulting tensions, then to resolve them in the promise of eternal life - the only real assurance of safety from war and from the more general inevitability of death. ${ }^{43}$

This process of conversion is in its general outlines remarkably similar to influential twentieth-century psychiatric notions of appropriate therapy for combat exhaustion or other traumatic stress. During World War II American military physicians in North Africa used drugs and hypnosis, as Civil War revivalists used their tracts and sermons, to revive "partially or completely forgotten traumatic battle episodes." As a result of this effort "repressed battle experience was restored to consciousness, thus losing most of its previous potential to evoke anxiety." Patients were encouraged to explore emotions that had been denied and to release unmanageable anxiety through abreaction..$^{44}$

Civil War conversions and twentieth-century treatments for combat stress should not, of course, be seen as identical or interchangeable processes. The pious would object to such a rationalization of belief, while psychologists would regard such an equation as an undue mystification of the scientific. Undoubtedly they would point as well to the important differences in the populations under study and to their contrasting contexts and circumstances. Yet the similarities in soldiers' responses in the two eras are difficult to ignore, especially in the way they point to the profound dislocation experienced by so many Civil War soldiers. Like combatants in more recent wars, Confederate soldiers found themselves personally unprepared to cope with the ways that battle threatened both their existence and their identity. Adjustment and survival required personal transformation. The cult of the Lost Cause in the postwar years and the

\footnotetext{
${ }^{43}$ For the identification of religion as war see other examples: Can I Be Religious While I Am A Soldier? (Richmond, [186-]); Charles F[orce]. Deems, "Christ in You" (Raleigh, [186-]), 2; Bread Upon the Waters, or a True Story of Lucknow (Petersburg, Va., [186-]), 2; [Herbert T. Bacon], The Countersign (Richmond, [186-]); The Muster (Charleston, [186-]); B[asil]. Manly, Jr., Halting on this Side of Jordan . . . (Raleigh, [186-]).

${ }^{44}$ Brill, "Gross Stress Reactions," 1032 (first quotation); Albert J. Glass, "Psychotherapy in the Combat Zone," American Journal of Psychiatry, CX (April 1954), 727 (second quotation). On guilt and its role in war neuroses see Bartemeier et al., "Combat Exhaustion"; Southard, Shell-Shock, 256; Joseph Lander, "The Psychiatrically Immunizing Effect of Combat Wounds," American Journal of Orthopsychiatry, XV (July 16, 1946), 536-41. On suggestibility in early stages of combat stress see Glass, "Psychotherapy in the Combat Zone," 726. For a discussion of guilt as a standard vehicle of conversion see Edmund S. Morgan, Visible Saints: The History of a Puritan Idea (New York, 1963); Murray G. Murphey, "The Psychodynamics of Puritan Conversion," American Quarterly, XXXI (Summer 1979), 13547; and John Lofland and Norman Skonovd, "Conversion Motifs," Journal for the Scientific Study of Religion, XX (December 1981), 373-85.
} 
numerous continuities between Old South and New should not lull us into forgetting that in significant ways the Civil War created new men.

Students of comparative psychiatry have emphasized that anxiety is interpreted and treated in markedly different ways in different cultural settings. What appears as an intense and debilitating conviction of sin in one era may in a more secular and rationalistic age become a case of "shell shock" or "combat exhaustion" that responds to medical treatment ${ }^{45}$ Within southern culture of the 1860 s, religion was the obvious cultural resource for explaining and relieving such deeply felt distress. For the common soldier, therefore, Evangelicalism offered a vehicle of personal reintegration and a means of dealing with the physical and psychological assaults of war upon his individual humanity - and even his continued existence. As one private reported to a sympathetic evangelist, "But for the comfort of religion, he thinks he would have lost his mind." ${ }^{46}$ The clergy, in turn, found for themselves in war a role of enhanced secular usefulness and importance as well as authentic spiritual fulfillment in the saving of so many souls. For military leaders, revivalism promised a means of inculcating a necessary spirit of discipline and subordination in southerners not previously required to possess such virtues; it was also a way of ensuring the continued favor of the God of Battles.

But the significance of Confederate revivals transcends their meaning for the specific groups involved. Evangelical enthusiasm reflected not just religious but widespread social and cultural tensions that found expression in an evangelical idiom, a discourse that points to the wartime emergence of frictions that were to persist and to grow in the postwar South. Although religion had been at the center of traditional southern identity, it ironically and necessarily became in the army the vehicle and symbol of broader cultural innovation and change. It was religious language that demanded soldiers' adoption of values and behavior representing sharp departures from their accustomed way of life; it was religious exhortation that sought to resolve the social conflicts disrupting Confederate camps by imposing discipline on hitherto "independent" farmers.

In the crucible of war, the consensus that had characterized antebellum white society was to break down. Demands for mobilization of men and resources created troubling wartime divisions over the operation of conscription and impressment laws and over the distri-

45 J. Milton Yinger, The Scientific Study of Religion (New York, 1970), 152; Julian Silverman, "Shamans and Acute Schizophrenia," American Anthropologist, LXIX (February 1967), 21-31. See Bourne, Men, Stress, and Vietnam, 79, on cultural influences in differences in reactions to combat of Americans and Vietnamese.

46 Biblical Recorder, September 2, 1863. 
bution of newly scarce necessities of life. And when economic deprivation emerged as an unfamiliar reality for white southerners, social divisions that had been only intermittently visible in the prewar years intensified until they threatened the Confederacy's very survival. Individualistic southern yeomen found it difficult to adjust to the hierarchy required by war and to what many viewed as the disproportionate sacrifices expected of them. These growing conflicts appeared within the context of army religion as differences of personal and cultural values over issues such as temperance, cleanliness, profanity, and self-discipline. But ultimately the frictions became much more overt, as they were expressed first in wartime desertions and disloyalties and later in the class-based political activity of the postbellum years. ${ }^{47}$

Yet Evangelicalism remained central within this strife even after Appomattox. The postwar era was a time of dramatic growth for southern churches, for the revival spirit seemed to follow soldiers home from the camps. On the one hand, Evangelicalism became, as Charles Reagan Wilson has argued, the language of defense for the old order and the Lost Cause. Yet at the same time the New South vision of modernity and industrial progress also assumed an evangelical idiom. By the 1890 s the church seemed so closely allied with the business class that North Carolina Populists directly attacked religious discipline as an instrument of the class hegemony that they perceived to have grown so oppressive in the years since the close of the war. But these Populists did not reject Evangelicalism entirely. Instead, like common soldiers three decades before, they too had their uses for revivalism and an alternative vision of its significance, not so much as a form of discipline but as a means of empowerment. ${ }^{48}$

The broader significance of army religion may thus be the way in

${ }^{47}$ On social conflict see Paul D. Escott, “'The Cry of the Sufferers': The Problem of Welfare in the Confederacy," Civil War History, XXIII (September 1977), 228-40; Hahn, The Roots of Southern Populism, 86-133; Stephen E. Ambrose, "Yeoman Discontent in the Confederacy," Civil War History, VIII (September 1962), 259-68; Georgia Lee Tatum, Disloyalty in the Confederacy (Chapel Hill, 1934); Ella Lonn, Desertion During the Civil War (New York, 1928); Bessie Martin, Desertion of Alabama Troops from the Confederate Army: A Study in Sectionalism (New York and London, 1932); Maurice Melton, "Disloyal Confederates," Civil War Times Illustrated, XVI (August 1977), 12-19.

${ }^{48}$ On the postwar period see Charles Reagan Wilson, Baptized in Blood: The Religion of the Lost Cause, 1865-1920 (Athens, Ga., 1980); Rufus B. Spain, At Ease in Zion: A Social History of Southern Baptists, 1865-1900 (Nashville, 1967); Hunter Dickinson Farish, The Circuit Rider Dismounts: A Social History of Southern Methodism, 1865-1900 (Richmond, 1938); and Ernest Trice Thompson, Presbyterians in the South: 1861-1890 (3 vols.; Richmond, 1973), II. On Populists and religion see Frederick A. Bode, Protestantism and the New South: North Carolina Baptists and Methodists in Political Crisis, 1894-1903 (Charlottesville, Va., 1975); Bode, "Religion and Class Hegemony: A Populist Critique in North Carolina," Journal of Southern History, XXXVII (August 1971), 417-38; and Robert C. McMath, Jr., Populist Vanguard: A History of the Southern Farmers' Alliance (New York, 1975), 75. 
which it points to the importance of the experience of war itself in establishing a framework for the social and political conflicts of a New South. In the Confederate army, as in the South of the postwar years, the protean nature of the evangelical message permitted its adherents to appropriate it to satisfy very different purposes and needs. Revivalism served at once as an idiom of social strife and a context for social unity in an age of unsettling transition; it became a vehicle both for expression and resolution of conflict about fundamental transformations in the southern social order.

The identity crisis of the Confederate soldier adjusting to distressing new patterns of life and labor was but a microcosm of the wartime crisis of a South in the throes of change. Military service inaugurated for many southerners a new era characterized by a loss of autonomy and self-determination that even peace would not restore. In the postwar years a southerner was far more likely to be a tenant and far less likely to be economically self-sufficient than he had been in the antebellum period. He might even follow his experience of military wage labor with that of factory employment, as the cotton mill campaign drew thousands of white southerners into industry. ${ }^{49}$

But perhaps the most profound transformation for many Confederate soldiers was deeply personal. In the past decade we have been made sharply aware of the lingering effects of another lost war upon its veterans years after their return to civilian life. Irrational outbursts of violence and debilitating depression are but two characteristic symptoms of what psychiatrists have come to see as a definable "post-Vietnam" syndrome. Southerners deeply scarred by their experiences of horror in the world's first total war may have been affected in similar ways. Perhaps part of the explanation for the widespread violence of the postwar South should be psychological; Klan activity, whitecapping, and lynching may have been a legacy of soldiers' wartime stresses as well as a political response to new and displeasing social realities..$^{50}$

In the clues that it offers to the profound impact of battle and to the social origins of a new South, revivalism is central to the Confederate experience. The Civil War challenged both the South and her fighting men to be "born again."

\footnotetext{
${ }^{49}$ See Hahn, Roots of Southern Populism, 137-289; Forrest McDonald and Grady McWhiney, "The South from Self-Sufficiency to Peonage: An Interpretation," American Historical Review, LXXXV (December 1980), 1095-1118; and Broadus Mitchell, The Rise of Cotton Mills in the South (Baltimore, 1921).

${ }^{50}$ Hendin and Haas, Wounds of War. See also the striking descriptions of postwar southern "lethargy and listlessness" that sound much like other, less violent manifestations of postVietnam syndrome, in Dan T. Carter, When the War Was Over: The Failure of SelfReconstruction in the South, 1865-1867 (Baton Rouge and London, 1985), 271. See also David Herbert Donald, "A Generation of Defeat," in Walter J. Fraser, Jr., and Winfred B. Moore, Jr., eds., From the Old South to the New: Essays on the Transitional South (Westport, Conn., 1981), 3-20.
} 